\title{
Obszary współpracy między uczelnią, biznesem a samorządem w zakresie przekształceń przestrzeni zurbanizowanej
}

\section{Cooperation of university, local government and business in the process of city space transition}

\section{Streszczenie}

Celem artykułu jest identyfikacja i opis wzajemnych powiązań i obszarów współpracy między uczelnią, biznesem a samorządem. Ich współdziałanie jest warunkiem powodzenia podjętych zadań. Efektywność współpracy uczelni, biznesu i samorządu w zmieniających się warunkach ekonomicznych i społecznych wpływa bowiem na jakość uzyskanych rezultatów. Każdy z podmiotów formułuje strategie i cele działania, uwzględniając współdziałanie z partnerami. Kolejnym celem artykułu jest sformułowanie przesłanek do modelu współpracy, który uwzględniając różnice misji i zadań uczelni, biznesu oraz samorządu, wzmacniałby i przyspieszał działania na rzecz przekształceń przestrzeni zurbanizowanej. Włączenie społeczności lokalnych w opisane działania byłoby ważnym elementem realizacji celów zrównoważonego rozwoju. Istnieje bogata praktyka inicjowania i realizacji projektów na rzecz przestrzeni zurbanizowanej w różnej skali przy udziale trójkąta: uczelnia, biznes, samorząd. W artykule zaprezentowany zostanie case-study: Projekt placu Długosza w Raciborzu.

Słowa kluczowe: model współpracy, rozwój zrównoważony, przestrzeń zurbanizowana

\begin{abstract}
The aim of the paper is to identify and describe the interrelationships and fields of cooperation between university, local government and business. The effectiveness of this cooperation in constantly changing economic and social conditions influences the quality of results. Entities representing business, local government and university formulate their objectives and strategies separately but including future relationships with the partners. Another aim of this paper so is to propose prerequisites for such a model of cooperation university - business - local government that might strengthen and accelerate city space transitions. Incorporating local communities into these activities may help achieving sustainable development goals. There is already a rich practice of initiating and implementing projects for the city space at various scales involving partners as university, business and local government. This paper will present one of them, a case study: Dlugosz Square Project in Raciborz.
\end{abstract}

Keywords: model of cooperation, sustainable development, urban space 


\section{CELE I WARUNKI WSPÓŁDZIAŁANIA UCZELNI WYŻSZYCH, BIZNESU I SAMORZĄDÓW W SKALI LOKALNEJ I REGIONALNEJ}

Otoczenie społeczno-gospodarcze i kulturowe definiuje obszary współpracy uczelni, biznesu i samorządu oraz wpływa na jej formę oraz jakość uzyskanych rezultatów. Na przestrzeni wieków uczelnie wyższe pomnażały wiedzę, opisywały i poddawały analizie zjawiska występujące w otaczającym świecie oraz kształciły studentów - przyszłych specjalistów w ważnych społecznie zawodach oraz młodych adeptów nauki. Współdziałały ze swoimi odpowiednikami w innych miastach i krajach, tworząc płaszczyznę wymiany myśli, dyskusji hipotez badawczych, uzgadniania rezultatów badań naukowych, prowadzenia eksperymentów i wdrażania wynalazków. To właśnie dzięki osiągnięciom nauki powstał i rozwinął się przemysł, a społeczeństwa uległy głębokim przekształceniom. Nauka stanęła zatem wobec kolejnych zadań i wyzwań, a uczelnie podjęły zadanie kształcenia kadr dla przemysłu.

Wraz z rozwojem przemysłu w drugiej połowie XVIII wieku i wprowadzeniem produkcji mechanicznej rozpoczęła się sekwencja kolejnych tzw. rewolucji przemysłowych. Symbolem pierwszej z nich było wprowadzenie produkcji mechanicznej wspomaganej siłą wody i pary wodnej. Druga, na początku XX wieku, wprowadziła nową jakość (i efektywność) produkcji za sprawą wykorzystania energii elektrycznej i zastosowania linii produkcyjnej. Trzecia rewolucja przemysłowa, zwana rewolucją naukowo-techniczną, dokonała się w latach 70. XX wieku za sprawą wykorzystania technologii informatycznych i cyfryzacji produkcji.

Dziś jesteśmy świadkami czwartej rewolucji przemysłowej. Przemysł 4.0 polega na integracji systemów oraz tworzeniu sieci i integracji ludzi ze sterowanymi cyfrowo maszynami, szeroko wykorzystującymi Internet oraz technologie informacyjne. Nieograniczony dostęp do informacji w dowolnym czasie, z dowolnego miejsca pozwala na opłacalną produkcję zindywidualizowanych wyrobów i krótkich serii produkcyjnych. Firmy mogą uzyskać elastyczność $w$ dostosowaniu się do oczekiwań klientów, a więc także przewagę nad konkurencją ${ }^{1}$. Powstały już i powstają nowe zawody, od pracowników wymaga się inaczej niż dotychczas skonfigurowanej wiedzy i umiejętności. Środowiska biznesowe oczekują zatem od uczelni wyższych przygotowania pracowników o zupełnie nowych kompetencjach.

W tle nowej rewolucji przemysłowej dokonuje się zmiana paradygmatu gospodarki liberalnej w kierunku rozwoju zrównoważonego². Konieczność ochrony zasobów ziemi i racjonalnego gospodarowania jej zasobami stają się bowiem warunkami przetrwania cywilizacji.

Przestrzeń zurbanizowana podlega dynamicznym przekształceniom na skutek intensywnych procesów urbanizacji. Przemysł 4.0 i idea rozwoju zrównoważonego kształtują ramy tych przekształceń i nadają im kierunek. Dzięki nowej rewolucji technologicznej projektant - architekt/urbanista zyskał efektywne narzędzia wspomagające jego pracę. Komputerowe wspomaganie projektowania oferuje dziś narzędzia, które radykalnie zmieniają warsztat architekta, a także jego sposób myślenia o układach urbanistycznych, budynkach i procesie ich realizacji. Zwalniają go również z szeregu rutynowych czynności i oszczędzają czas, który 
w procesie przygotowania projektu można przeznaczyć na kreację. Mowa tu o modelowaniu parametrycznym, które rozpowszechnia się i staje się regularnie stosowane w praktyce projektowej. Logika projektowania parametrycznego dobrze wpisuje się w procesy charakteryzujące czwartą rewolucję przemysłową: pozwala na zindywidualizowane podejście do zadań projektowych, przyspieszenie procesu projektowania, łatwość modyfikacji rezultatów, optymalizację formy urbanistycznej/architektonicznej oraz doboru i wykorzystania materiałów³. Co istotne, dzięki modelowaniu parametrycznemu można w sposób efektywny kształtować przestrzeń zrównoważoną.

Zasygnalizowane procesy, związane z czwartą rewolucją przemysłową, charakteryzują się różną intensywnością w poszczególnych krajach - najszybciej zachodzą w najwyżej rozwiniętych krajach Europy i w USA. Są one również widoczne, choć nie dominujące, w Polsce. Należy jednak przypuszczać, że wraz z dalszym rozwojem ekonomicznym i społecznym kraju absorpcja rozwiązań technologicznych charakterystycznych dla ery przemysłu 4.0 będzie postępować w szybkim tempie.

\section{UCZELNIA - BIZNES - SAMORZĄD: WZAJEMNE OCZEKIWANIA}

Czwarta rewolucja przemysłowa stanowi ważną przesłankę kształtowania relacji między uczelnią, biznesem i samorządem. Funkcjonujące dziś powiązania okażą się niebawem niewystarczające i nie dość efektywne dla zapewnienia dalszego rozwoju jednostek terytorialnych, a zwłaszcza miast.

W europejskim kręgu kulturowym uniwersytety, począwszy od swojego powstania, były powiązane z miastami. Pierwotnie fundowane przez władców/mecenasów, a następnie z inicjatywy elit i środowisk twórczych, uczelnie zawsze pełniły ważną kulturową rolę w miastach i były stymulatorami ich rozwoju. Również i dziś obecność uczelni w mieście jest ważnym czynnikiem miastotwórczym, a jej rola, w porównaniu do czasów sprzed pierwszej rewolucji przemysłowej, uległa znacznemu poszerzeniu. Wzrosły również oczekiwania ze strony samorządu i biznesu w stosunku do uczelni „swoich”, czyli położonych w mieście -najczęściej stolicy regionu.

Miejskie samorządy oczekują od uczelni podejmowania zadań eksperckich oraz kształcenia kadr o wysokich kwalifikacjach, które zasiliłyby lokalny i regionalny rynek pracy. Są gotowe stworzyć system zachęt, skłonnych zatrzymać najlepszych absolwentów w mieście, zwłaszcza gdy reprezentują oni deficytowe zawody. Uczelnia jest także ważnym partnerem w realizacji strategii miasta: może kreować i wspomagać działania o charakterze innowacyjnym i przyczyniać się do poprawy wizerunku miasta (il. 1). Co ważne, wspólne inicjatywy i działania miasta oraz uczelni mogą służyć zrównoważonemu rozwojowi miasta i regionu.

Środowiska biznesowe, podobnie jak samorząd, liczą na możliwość zatrudnienia absolwentów lokalnej uczelni pod warunkiem posiadania przez nich nowocześnie 
skonfigurowanego wykształcenia, najlepiej o profilu praktycznym. Firmy oczekują ze strony uczelni generowania użytecznych dla nich rozwiązań innowacyjnych oraz kreowania i wdrażania wynalazków. Są gotowe do ścisłego współdziałania w tym zakresie, począwszy od formułowania zadań badawczych przez ich współfinansowanie i sprawną komercjalizację (il. 2). Przedsiębiorcy chętnie wykorzystują pracowników uczelni jako ekspertów i opiniodawców. Korzystają także z rezultatów prac studenckich kół naukowych.

Przegląd oczekiwań wobec uczelni wyższej ze strony samorządu i biznesu pozwala stwierdzić, że współpraca z tymi partnerami jest jednym ze stymulatorów rozwoju współczesnej uczelni. Dla uczelni (jako instytucji) jest niezwykle ważne, by była ona długofalowa i stabilna. Mogą to zapewnić oferowane przez samorząd i biznes pakiety rozwiązań organizacyjnych, prawnych i finansowych, które powinny wspierać rozwój infrastruktury uczelni, tworzyć ramy dla zamawianych przedsięwzięć badawczych, studiów, ekspertyz i opinii zlecanych pracownikom i studentom (il. 3).

Samorząd i przedsiębiorcy (jako potencjalni pracodawcy) to partnerzy uczelni, których rola w kształtowaniu oferty dydaktycznej jest bardzo istotna. Konsultowanie programów studiów, realizacja poszczególnych przedmiotów oraz rozbudowanych praktyk studenckich, m.in. w ramach studiów dualnych, to warunki pozwalające dostosować program studiów, a w efekcie kompetencje absolwentów do wymogów rynku pracy. Partnerzy uczelni mogą zatem mieć duży wkład w realizację jej celów strategicznych. Praktyka współpracy zależy od prowadzonych przez uczelnię badań naukowych i oferowanych kierunków studiów. Środowiska gospodarcze najchętniej współpracują z pracownikami i studentami informatyki, automatyki i robotyki czy inżynierii produkcji, władze samorządowe współdziałają natomiast z uczelnianym środowiskiem skupionym wokół problematyki społecznej (np. administracja, bezpieczeństwo państwa).

Niezwykle istotnym obszarem wspólnych działań uczelni, samorządu i biznesu jest kształtowanie przestrzeni zurbanizowanej w mieście i regionie. Ten niezwykle skomplikowany i długofalowy proces, który w rezultacie określa szanse rozwojowe miasta/regionu, wymaga współpracy w ramach interdyscyplinarnego zespołu specjalistów. W procesie tym powinni uczestniczyć architekci i adepci architektury - pracownicy uczelni i jej studenci.

Architekci skupieni wokół uczelni mogą efektywnie wspomagać władze miasta i lokalny biznes zarówno w formułowaniu problemów przestrzennych, jak i wskazywaniu sposobów ich rozwiązania. Jednym z ważnych nurtów takiej aktywności jest działalność doradcza i ekspercka: ocena już opracowanych studiów i projektów, dyskusja nad celami i zakresem planowanych opracowań, inicjowanie konkursów architektonicznych i pomoc w ich przeprowadzeniu (np. udział w jury). W pracach tych, na zaproszenie uczelni, mogą także uczestniczyć przedstawiciele SARP-u i Izby Architektów, co podnosi rangę przedsięwzięcia i zwiększa jego merytoryczną wartość. Dużą wartość edukacyjną i wizerunkową dla miasta i regionu mają organizowane wspólnie konferencje naukowe.

Istotną wspomagającą rolę w realizacji opisanych celów mają projekty studenckie rozwiązujące zagospodarowanie miejskich terenów, zwłaszcza tych trudnych: położonych 
w centrach miast, obejmujących zespoły zabudowy cennej historycznie bądź obszary o dużej wartości krajobrazowej. Projekty studenckie stanowią znakomity materiał do dyskusji o optymalnych scenariuszach przyszłych działań na takich terenach lub wręcz podpowiadają gotowe rozwiązania. Studia i analizy wykonane w ramach takich projektów mogą trafnie wskazać najlepszą funkcję, rodzaj czy intensywność planowanej zabudowy. Takim przykładem będzie w tym opracowaniu studium przypadku - projekt placu Długosza w Raciborzu.

\section{STUDIUM PRZYPADKU: PLAC DŁUGOSZA W RACIBORZU}

\subsection{ANALIZA UWARUNKOWAŃ HISTORYCZNYCH, PRZESTRZENNYCH I SPOŁECZNO- -EKONOMICZNYCH}

Racibórz - miasto znajdujące się na granicy Górnego Śląska i Opolszczyzny liczy 50 tys. mieszkańców. Państwowa Wyższa Szkoła Zawodowa w Raciborzu jest jedyną uczelnią w mieście. W jej ramach funkcjonuje Instytut Architektury, który od początku swego istnienia (2012) kładzie nacisk na ścisłą współpracę z miastem i lokalnym biznesem. Jednym z ważniejszych tematów podjętych przez pracowników i studentów PWSZ był projekt placu Długosza.

Racibórz w 2017 roku obchodzi swoje 800-lecie. Charakterystyczny średniowieczny układ urbanistyczny, zamknięty pierwotnie w obrębie murów, jest czytelny w dzisiejszym planie miasta. Okres prosperity po uruchomieniu linii kolejowej w drugiej połowie XIX wieku zaowocował powstaniem intensywnej zabudowy o większej skali zarówno w obrębie dawnych murów, jak i w nowych dzielnicach, które założono na obszarach dawnych wsi przylegających do granic Raciborza ${ }^{4}$. Fotografie z lat 20. i 30. XX wieku pokazują piękne, zamożne miasto, już wówczas zamieszkałe przez 50 tys. mieszkańców. Zniszczenia wojenne w 1945 roku dotknęły 85\% zabudowy. Przestały istnieć całe kwartały zabudowy, obiekty przemysłowe, a także budynki o dużej wartości historycznej, w tym gotyckie i neogotyckie kościoły czy secesyjne kamienice. Pojedyncze zabytki z pietyzmem odbudowano i częściowo odtworzono zabudowę mieszkaniowo-usługową ścisłego centrum, stosując w architekturze najpierw formy charakterystyczne dla socrealizmu, a następnie, począwszy od wczesnych lat 60. XX wieku, formy modernistyczne ${ }^{5}$. Niektóre obszary centrum miasta po zniszczeniach wojennych pozostały niezabudowane do dnia dzisiejszego. Największym niezabudowanym terenem o powierzchni 0,8343 ha, narożnikiem przylegającym do rynku Starego Miasta, jest plac Długosza. Północną i południową pierzeję placu dzieli aż 190 m, co sprawia, że dla tak dużego obszaru, znajdującego się w obrębie murów miejskich, trudno zaproponować funkcję i znaleźć inwestora. Plac służy obecnie jako miejski parking, ale funkcja ta była od początku traktowana jako tymczasowa zarówno przez władze, jak i przez mieszkańców. Wraz 
z poprawą gospodarczą w Polsce po 1990 roku otworzyły się nowe możliwości poprawy tej jakże ważnej przestrzeni publicznej w mieście.

Zgodnie z zapisami planu miejscowego obszar placu Długosza powinien docelowo pełnić funkcję usługową. W 2005 roku władze miasta postanowiły sprzedać znaczną część terenu prywatnemu inwestorowi. Rozpoczęły się procedury przetargu, w którym cena wywoławcza wyniosła około $16 \mathrm{mln}$ złotych. Celem było przyciągnięcie poważnego inwestora, który mógłby zbudować na placu Długosza centrum handlowe. Zdaniem władz nowe centrum handlowe, zlokalizowane w centrum miasta, pomogłoby pobudzić lokalną gospodarkę i handel, a także ożywić okolicę. Jednak mimo systematycznego obniżania ceny w kolejnych przetargach nieruchomość nie znalazła nabywcy. W międzyczasie jednak centra handlowe obsługujące mieszkańców Raciborza wzniesiono w innych lokalizacjach, powróciła zatem kwestia zagospodarowania tak dużej przestrzeni publicznej w centrum miasta w inny sposób niż przez wzniesienie obiektu wielkogabarytowego. Mieszkańcy zapytani w sondażach o przyszłe wykorzystanie placu w większości odrzucali ideę intensywnej zabudowy placu, akceptując jednocześnie ewentualne urządzenie terenów rekreacyjnych.

W takim momencie, w 2014 roku rozpoczęła się współpraca Instytutu Architektury z władzami miasta i przedstawicielami biznesu, dotycząca zagospodarowania placu Długosza. Uznano, że zagospodarowanie tak ważnej przestrzeni, znajdującej się w sercu starego miasta, wymaga głębszej refleksji i kompetentnych studiów oraz analiz. Na ich podstawie miały powstać wytyczne do przyszłego - finalnego opracowania. Wnikliwe analizy historyczne przeprowadzone zostały przez pracowników i studentów we współpracy z Muzeum w Raciborzu, władzami miasta i mieszkańcami. Analiza materiałów archiwalnych, wizyty w terenie, spotkania i dyskusje z użytkownikami miasta doprowadziły do sformułowania następujących konkluzji:

\section{Znaczenie pierwotnego układu przestrzennego}

Pomimo zniszczeń wojennych i zmian, które zaszły w historycznym układzie starówki, powierzchnię obecnego placu Długosza należy podzielić na mniejsze sekcje, aby odzyskać pierwotną skalę i proporcje zabudowy. W tym sensie pierwotny układ urbanistyczny można by uznać za punkt wyjścia (pretekst) do ukształtowania przestrzeni placu i nadanie mu nowej, drobniejszej skali. Ślady dawnej zabudowy, wciąż obecne w przestrzeni (ukryte pod powierzchnią placu piwnice budynków i ich fundamenty), mogłyby stanowić podstawę zaproponowania rozwiązań przestrzennych respektujących „genetyczny kod miasta”.

\section{Skala nowej zabudowy}

Rozwój miasta można opisać za pomocą sinusoidy, gdzie cykle rozwoju przeplatają się z okresami zastoju czy upadku. Bezpośrednio po zakończeniu II wojny światowej Racibórz zamieszkiwało 3000 osób. Porównanie z liczbą ludności w 1939 roku, która wynosiła ponad 50 tysięcy, ilustruje skalę spadku. W latach 70. XX wieku miasto miało aż 70 tysięcy mieszkańców, liczba ta 
jednak w ostatnich 20 latach systematycznie spada i obecnie wynosi nieco poniżej 50 tysięcy. Liczba mieszkańców i kondycja gospodarcza miasta są ważnymi czynnikami determinującymi decyzje inwestycyjne. Po II wojnie światowej gęstość zaludnienia Starego Miasta uległa znacznemu zmniejszeniu. Odbudowano zabudowę obrzeżną ulic i placów, nie wypełniono jednak kubaturą wnętrz kwartałów, jak to się stało przed wojną. Wiele nowych zespołów mieszkaniowych, centrów handlowo-usługowych o różnej skali ulokowano w nowych dzielnicach. Planowanie dziś nowych obiektów kubaturowych na obszarze Starego Miasta jest obciążone znacznym ryzykiem i wymaga rzetelnej diagnozy przyszłych potrzeb przestrzennych inwestorów/użytkowników. Odtworzenie zwartej, intensywnej zabudowy placu Długosza może okazać się fiaskiem ze względu na brak inwestorów gotowych rozwinąć działalność w nowym kompleksie usługowym.

\section{Charakter nowej formy architektonicznej}

Większość budynków w Raciborzu po wojennych zniszczeniach została odtworzona w stylu eklektycznym. Obiekty zabytkowe starannie odbudowano zgodnie z informacjami archiwalnymi dokumentującymi ich pierwotną architekturę. W krajobrazie Starego Miasta widoczne są jednak także brzydkie modernistyczne bloki mieszkalne. Taka mozaika stylów utrudnia wszelkie interwencje architektoniczne: nie ma przeważającego stylu, który mógłby być zastosowany do ujednolicenia form urbanistycznych i architektonicznych. W tym przypadku metoda projektowania addytywnego, gdy każdy z wielu inwestorów zaangażowanych w przebudowę proponuje własne rozwiązania formalne, wydaje się kontrowersyjna. W takich warunkach skromna, „niewidzialna” architektura, a także koncepcje scenografii architektonicznej wydają się być akceptowalnymi rozwiązaniami.

\section{Funkcja nowej zabudowy}

Planowanie nowej funkcji dla placu Długosza skłania do zwrócenia się w stronę przeszłości. Przez wieki ta część miasta pełniła funkcję mieszkalną i handlową. Tradycyjne przemieszanie funkcji, charakterystyczne dla tej części centrum miasta w okresie przed II wojną światową (i wcześniej), jest już niemożliwe do odtworzenia. Największą barierę stanowi skala miasta: w Raciborzu niepotrzebne są nowe obiekty użyteczności publicznej czy kultury. Nowy kampus raciborskiej uczelni mógłby być uznany za opcję, ale fundusze na taką inwestycję byłyby trudne do zdobycia.

\section{Znaczenie miejsca, jego wizerunek i znaczenie dla mieszkańców}

Tożsamość miejsca w wymiarze lokalnym jest dla współczesnego człowieka ważniejsza niż zestaw uniwersalnych wartości, które sprawiają, iż czuje się on częścią globalnej społecznoścí. Silna i wartościowa tożsamość przestrzenna wymaga ciągłego rozwijania. Zniszczenia wojenne, katastrofy i migracje (deportacje) powodują osłabienie poczucia przynależności do miejsca.

Starsi wiekiem mieszkańcy Raciborza, częściej niż młodzi, afirmują przedwojenną świetność miasta. Gromadzą i przechowują pamiątki: książki, obrazy, zdjęcia, dokumenty 
archiwalne. Dla młodszych natomiast obecna forma przestrzeni to krajobraz za autentyczny. Identyfikacja ukształtowanego historycznie kodu identyfikacyjnego tożsamości miejsca ${ }^{7}$, a następnie stworzenie nowej tożsamości w sposób zrozumiały dla wszystkich użytkowników przestrzeni będzie wymagało pogodzenia dwóch różnych obrazów miasta.

\subsection{OPIS PROPOZYCJI PROJEKTOWYCH DLA PLACU DŁUGOSZA W RACIBORZU}

\section{A. Odtworzenie pierwotnej zabudowy z zachowaniem skali i pierwotnych linii zabudowy}

Propozycja projektowa „A” powraca do pierwotnego układu placu, który został zniszczony podczas II wojny światowej (il. 4A). Odtwarza plac Marcellusa i układ ulic do niego przylegający. Choć kubatura budynków jest zbliżona do pierwotnej, to ich formę uproszczono w porównaniu z przedwojennym układem (il. 5A). Zaproponowano komercyjne wykorzystanie budynków i ich podział na moduły przestrzenne, które pozwoliłby na sprawny wynajem powierzchni inwestorom. Część północna placu pozostaje bez zmian, gdzie zniszczone w czasie wojny budynki już wcześniej zastąpiono zielenią.

\section{B. Zdefiniowanie nowych osi urbanistycznych}

Przedwojenne Stare Miasto w Raciborzu składało się z heterogenicznych przestrzeni o różnym rozmiarze, charakterze, wydzielonych za pomocą miękko ukształtowanych linii ulic. Projekt „B” podejmuje próbę odtworzenia dawnej skali Starego Miasta. Proponuje trzy równoległe budynki przecięte przez dwie przekątne osie. Początkowe i końcowe punkty nowych osi są wyznaczone przez wieżę kościoła parafialnego (w północno-zachodnim rogu placu) i wieżę więzienną (na południu). Do pierzei wschodniej przylega nowy, niewielki plac, na którym usytuowano pomnik (il. 4B). Zaproponowany układ przestrzenny podkreśla dziedzictwo kulturowe, jednocześnie kreuje nowe wartości i pomaga w przestrzennej orientacji. Architektura nowych budowli ma charakter współczesny i jest zróżnicowana (il. 5B). Kompleks zaprojektowano jako kampus uniwersytecki.

\section{Zagospodarowanie placu Długosza na bazie śladów dawnej zabudowy. Podkreślenie walorów krajobrazowych terenu}

Po Il wojnie światowej z placu Długosza usunięto tony gruzu, a jego powierzchnię wyrównano, przykrywając fundamenty i piwnice zburzonych budynków. Prace archeologiczne, prowadzone w sąsiedztwie placu, odsłoniły wiele cennych śladów przeszłości, które wzbogaciły wiedzę na temat historii Raciborza. Spodziewane bogactwo kondygnacji podziemnej placu Długosza zainspirowało autorów propozycji „C", którzy zaproponowali na odsłonięcie wybranych piwnic i ścian fundamentowych. Stanowią one podstawę nowych, jednokondygnacyjnych, transparentnych budynków o kształcie sześcianu różnej wielkości. Są one połączone kładkami pieszymi poprowadzonymi nad odkrywkami (il. 4C). Sześcienne kostki miałyby 
służyć aktywności biznesowej. Fragmenty zachowanej poniżej tkanki miejskiej zostałyby wykorzystane w architekturze małych barów i kawiarni ulokowanych wśród zieleni (il. 5C).

\section{Korekta wielkości i kształtu placu}

Projekt „D” próbuje skorygować rozmiar placu Długosza, proponując wydzielenie dwóch odrębnych przestrzeni: miejskiego placu (od strony północnej) i strefy zieleni powiązanej z zachowanym fragmentem murów obronnych od południa. W tym celu zaprojektowano długi, prostokątny budynek o skromnej architekturze, mieszczący w zamierzeniu autorów muzeum przyrodnicze. Jego północna elewacja stanowi jednocześnie ścianę placu o zmniejszonym rozmiarze (il. 4D). Ściany centralnej części budynku muzeum są ze szkła, dzięki czemu zwiedzający mogą podziwiać zarówno panoramę miasta, jak i renesansową wieżę więzienną. To w założeniu nowa brama do miasta. Również w tym projekcie wykorzystano podziemne ruiny jako inspirację dla zagospodarowania części parkowej założenia (il. 5D).

Cztery zaprezentowane rozwiązania projektowe uwzględniły i przełożyły na język projektu urbanistycznego i architektonicznego rezultaty analiz i szerokich konsultacji. Niestety, możliwości finansowe miasta nie pozwalają obecnie na odbudowę placu Długosza według jednej z opracowanych koncepcji.

Tymczasowe zagospodarowanie tej jakże ważnej dla mieszkańców miasta przestrzeni było przedmiotem konkursu zorganizowanego przez Urząd Miasta w Raciborzu. Konkurs na opracowanie koncepcji architektonicznej rozbudowy istniejącego budynku oraz aranżacji terenu wokół budynku na placu Długosza, w ramach zadania „Nadanie nowej funkcji społecznej zdegradowanej przestrzeni Centrum Miasta Racibórz”, rozstrzygnięto w 2016 roku. Pozwolił on wyłonić koncepcję, na podstawie której opracowany zostanie projekt realizacyjny. Dotychczasowe analizy i projekty dla placu Długosza były pomocne zarówno w czasie prac nad sformułowaniem warunków konkursu, jak też jasno określiły kryteria oceny złożonych projektów. W skład jury weszli pracownicy Instytutu Architektury PWSZ w Raciborzu, a III nagrodę w konkursie zdobyli studenci Instytutu Architektury raciborskiej PWSZ (il. 6).

\section{PODSUMOWANIE}

Celem artykułu była diagnoza funkcjonowania trójkąta współpracy uczelnia - biznes - samorząd w skali lokalnej. Wykazano, że istnieje bardzo szerokie spektrum wzajemnych oczekiwań, a także realny potencjał współpracy instytucji i firm. Może on stymulować rozwój poszczególnych podmiotów, a jednocześnie przyczyniać się realizacji celów wspólnych. Relacje między partnerami i praktyka wzajemnej współpracy tworzą układ dynamiczny, który zmienia się pod wpływem zmian zachodzących wewnątrz podmiotów i czynników otoczenia.

Czwarta rewolucja przemysłowa generuje zupełnie nową, inną niż dotychczas, kombinację czynników określających kierunek rozwoju gospodarczego i społecznego w najbliższej 
przyszłości. Już dziś zmienia funkcjonowanie gospodarki, tworzy nowe wyzwania dla instytucji edukacyjnych i władz każdego szczebla oraz redefiniuje powiązania między partnerami. Świadomość i właściwa interpretacja zachodzących procesów pozwala lepiej wykorzystać ich potencjał. Nowe zjawiska powinny być wnikliwie obserwowane i badane, co należy do zadań uczelni wyższych. Ich funkcje eksperckie w bliskiej perspektywie będą miały coraz większe znaczenie dla firm i instytucji.

Współpraca władz lokalnych, środowisk biznesowych i uczelni jest niezwykle istotna w przypadku przekształceń przestrzeni zurbanizowanej. W artykule pokazano, na przykładzie ważnej przestrzeni publicznej w mieście Raciborzu, jak kompetentne powinny być wstępne studia i analizy przygotowujące właściwy projekt urbanistyczny i architektoniczny. W przypadku współpracy partnerów na rzecz projektu placu Długosza w Raciborzu bardzo istotne okazało się wzajemne poszanowanie kompetencji i właściwy podział zadań. Stworzyły one warunki dla działań kreatywnych, które są warunkiem uzyskania wartościowych rezultatów. Dzięki rewolucji technologicznej przestrzeń kreacji w pracy projektanta będzie się stopniowo poszerzać. Ważne, by równolegle do tej zmiany jakościowej powstały warunki do implementacji projektów innowacyjnych. 


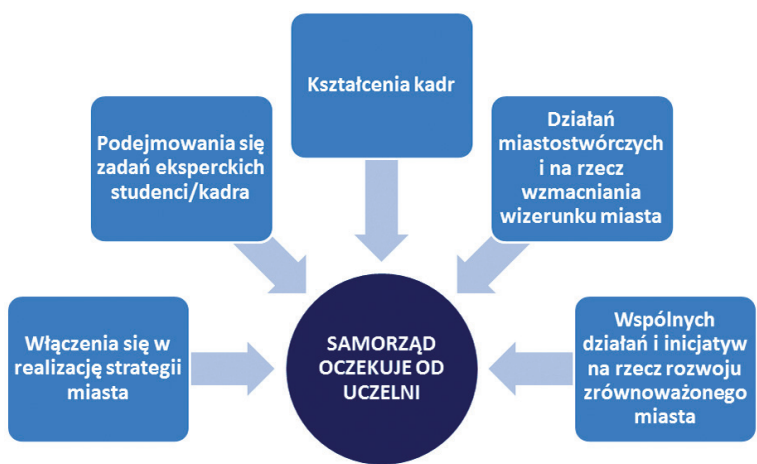

II. 1. Oczekiwania samorządu wobec uczelni wyższej działającej na terenie miasta (E. Stachura) III. 1. Expectations of the local authorities to the city university

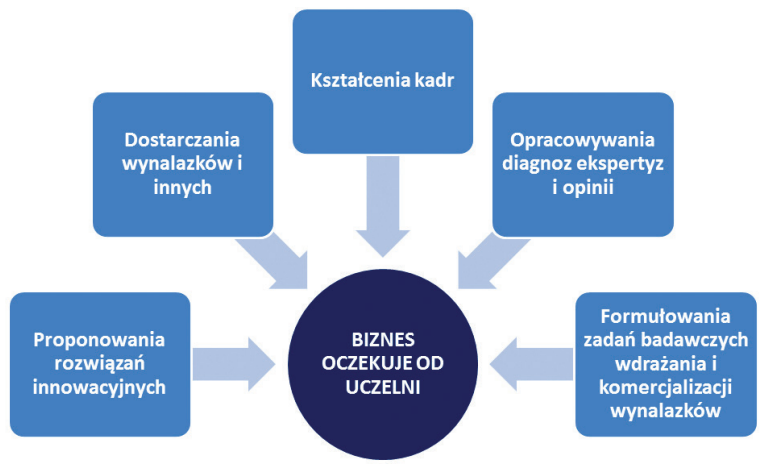

II. 2. Oczekiwania firm wobec uczelni wyższej działającej na terenie miasta (E. Stachura) III. 2. Expectations of MSE business to the city university
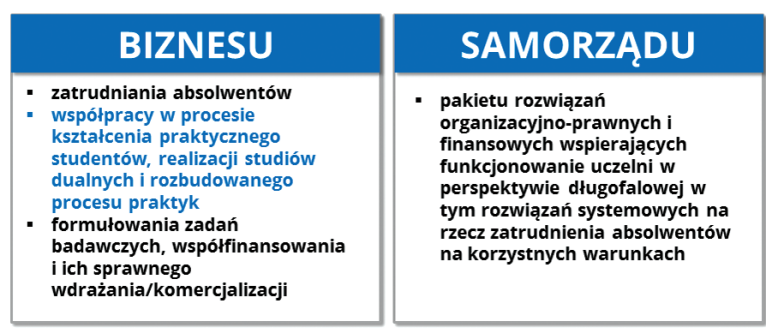

\section{BIZNESU I SAMORZĄDU}

- wsparcia finansowego/zadaniowego

- studiów przypadku - do rozwiązania przez kadrę/studentów - włączenia się w realizację strategii uczelni

II. 3. Oczekiwania uczelni wobec podmiotów otoczenia - firm i instytucji (E. Stachura) III. 3. Expectations of the university to entities representing local environment 

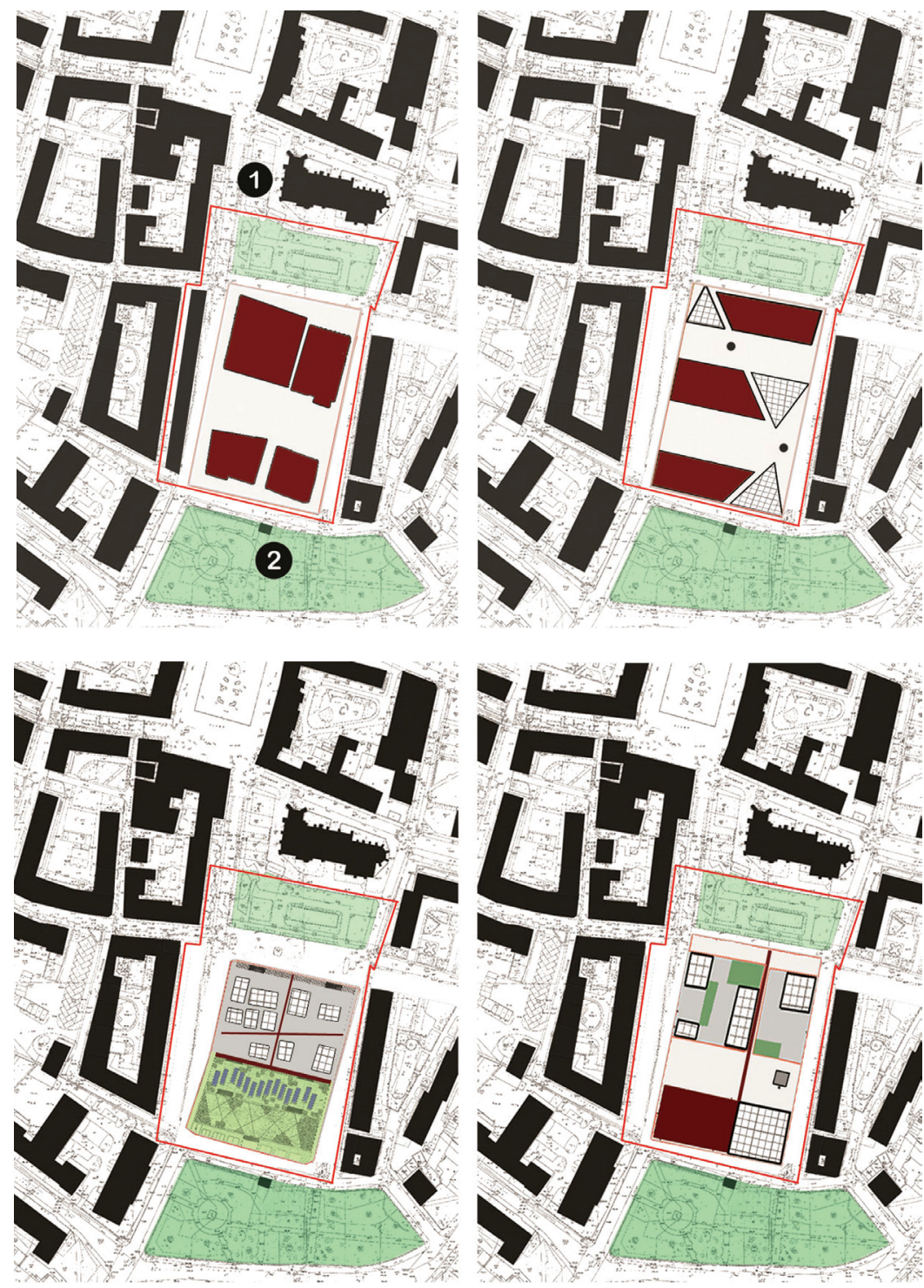

II. 4. Propozycje rozwiązania urbanistycznego dla placu Długosza w Raciborzu: A - odtworzenie pierwotnej zabudowy z zachowaniem skali i pierwotnych linii zabudowy, B - zdefiniowanie nowych osi urbanistycznych, $\mathrm{C}$ - zagospodarowanie placu Długosza na bazie śladów dawnej zabudowy i podkreślenie walorów krajobrazowych terenu, D - korekta wielkości i kształtu placu (E. Stachura)

III. 4. New urban layout for the Dlugosz Square in Raciborz proposals: A - Replicating development, respecting building lines and volumes, B - Defining new axes for the urban layout, C - Interpreting foundation walls footprints as the basic for the new square arrangement. Underlining landscape values of a square, D - Searching for the new shape of the Square 


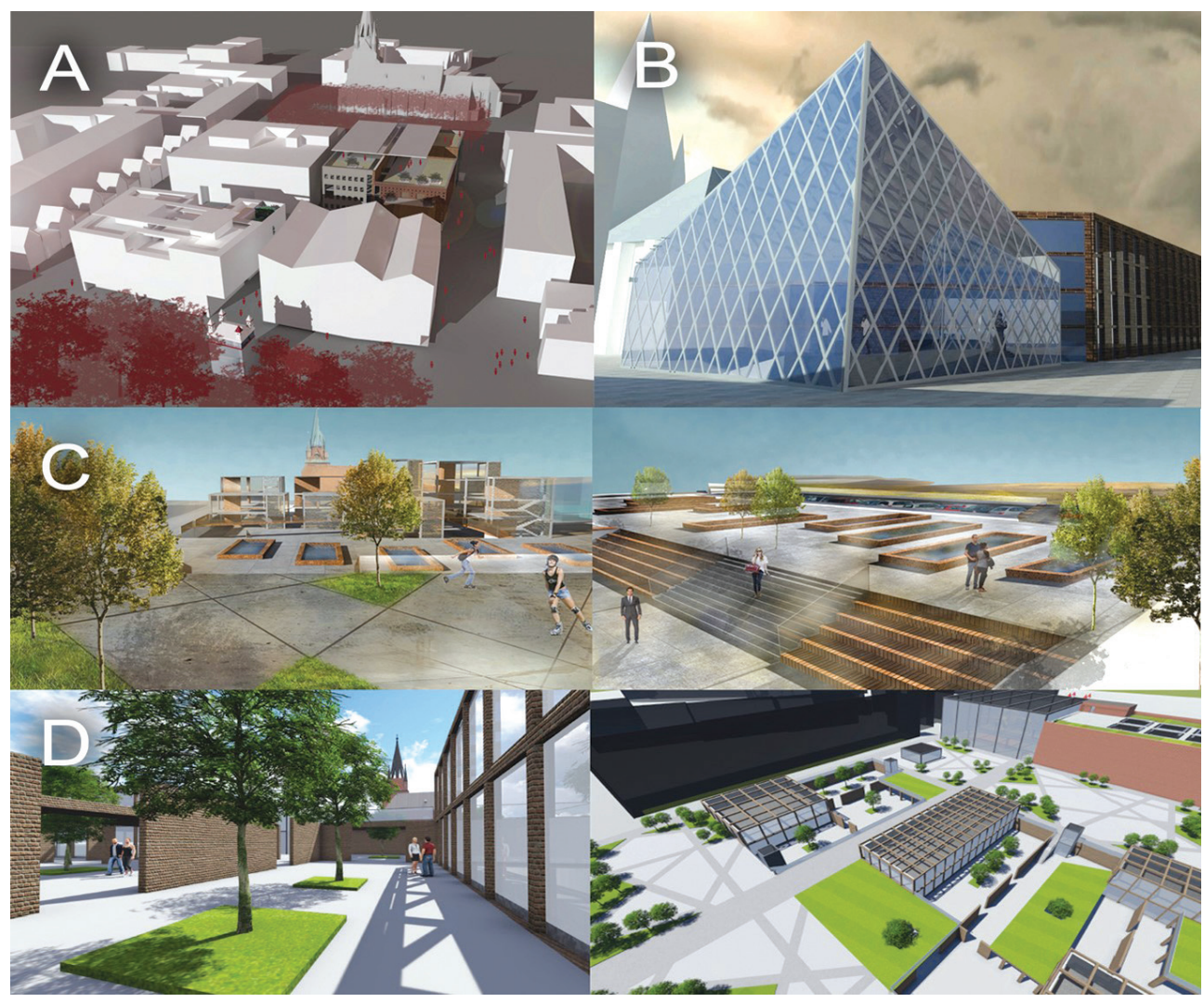

II. 5. Propozycje architektoniczne dla placu Długosza: A, B, C i D - odpowiednio dla czterech wersji projektu urbanistycznego (E. Stachura)

III. 5. Architectural design proposals for the Dlugosz Square: A, B, C, D (as marked on the picture 4)

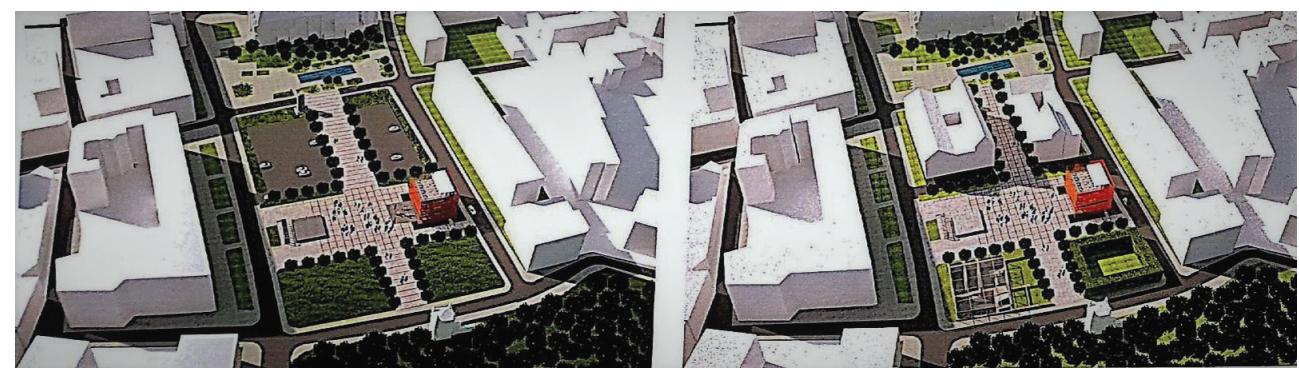

II. 6. Fragment projektu konkursowego na zagospodarowanie placu Długosza, zgłoszonego przez studentów PWSZ w Raciborzu (III nagroda w konkursie) (E. Stachura)

III. 6. Awarded students' project submitted to the Competition for the development of the Dlugosz Square in Raciborz 


\section{PRZYPISY}

1 P. Newerla, Dzieje Raciborza i jego dzielnic, Wydawnictwo i Agencja Informacyjna WAW Grzegorz Wawoczny, Racibórz 2008.

2 K. Lichtblau, Stich V, Bertenrath R., Blum M., Bleider M., Millack A., Schmitt K., Schmitz E., Schröter M., Industrie 4.0 Readiness, http://www.plattform-i40.de/140/Redaktion/EN/ Downloads/Publikation/vdma-readiness.html (dostęp: 1.09.2017).

3 M. Piasecki, Architektura i nowe technologie, „Architektura-Murator”, 10/2016 (265), s. 34-45.

4 P. Newerla, Dzieje Raciborza i jego dzielnic, Wydawnictwo i Agencja Informacyjna WAW Grzegorz Wawoczny, Racibórz 2008.

5 G. Wawoczny, Zabytki powiatu raciborskiego, Wydawnictwo i Agencja Informacyjna WAW Grzegorz Wawoczny, Racibórz 2007.

6 T. Burdzik, Przestrzeń jako składnik tożsamości w świecie globalizacji, „Kultura Historia Globalizacja”, nr 18, 2015, http://www.khg.uni.wroc.pl/files/2khg11_burdzik_t.pdf (dostęp: 1.09.2017).

7 J. Wrana, Tożsamość miejsca, kryterium w projektowaniu architektonicznym, Politechnika Lubelska, Lublin 2011, http://bc.pollub.pl/Content/646/tozsamosc.pdf (dostęp: 30.08.2017).

8 Autorzy projektów opisanych w tekście: A) Agata Kandora, Dominika Odelga, Aneta Skupch, Katarzyna Szymańska; B) Mateusz Małyska, Katarzyna Mańka; C) Martyna Dziurska, Karolina Krupa, Justyna Lebiedzik; D) Łukasz Bizoń, Lidia Flak. Prowadzący: dr hab. inż. arch. Ewa Stachura, dr inż. arch. Henryk Zubel.

\section{BIBLIOGRAFIA}

Burdzik T., Przestrzeń jako składnik tożsamości w świecie globalizacji, „Kultura Historia Globalizacja”, nr 18, 2015, http://www.khg.uni.wroc.pl/files/2khg11_burdzik_t.pdf (dostęp: 1.09.2017).

Hermann M., Otto B., Pentek T., Design Principles for Industrie 4.0 Scenarios: A Literature Review, Technische Universität Dortmund Fakultät Maschinenbau, Working Paper, No. 01/ 2015, http://www.snom.mb.tu-dortmund.de/cms/de/forschung/Arbeitsberichte/ Design-Principles-for-Industrie-4_0-Scenarios.pdf (dostęp: 25.08.2017).

Lichtblau K., Stich V, Bertenrath R., Blum M., Bleider M., Millack A., Schmitt K., Schmitz E., Schröter M., Industrie 4.0 Readiness, http://www.plattform-i40.de/140/Redaktion/EN/ Downloads/Publikation/vdma-readiness.html (dostęp: 1.09.2017).

Newerla P., Dzieje Raciborza i jego dzielnic, Wydawnictwo i Agencja Informacyjna WAW Grzegorz Wawoczny, Racibórz 2008.

Piasecki M., Architektura i nowe technologie, „Architektura-Murator”, 10/2016 (265), s. 34-45. Wawoczny G., Zabytki powiatu raciborskiego, Wydawnictwo i Agencja Informacyjna WAW Grzegorz Wawoczny, Racibórz 2007.

Wrana J., Tożsamość miejsca, kryterium w projektowaniu architektonicznym, Politechnika Lubelska, Lublin 2011, http://bc.pollub.pl/Content/646/tozsamosc.pdf (dostęp: 30.08.2017). 